\title{
Aerobic production of methane from dissolved water-column methylphosphonate and sinking particles in the North Pacific Subtropical Gyre
}

\author{
Daniela A. del Valle*, David M. Karl \\ Daniel K. Inouye Center for Microbial Oceanography: Research and Education, University of Hawaii, \\ 1950 East-West Road, Honolulu, Hawaii 96822, USA
}

\begin{abstract}
Supersaturation of methane in aerobic surface waters is a phenomenon widely observed in the ocean, albeit poorly understood. Recent studies have shown that degradation of methylphosphonate (MPn) can lead to the production of methane under aerobic conditions; however, the importance of this process has not been quantified under natural conditions. Here, we quantified the production of methane from dissolved MPn (d-MPn) in surface waters and observed that this process cannot account for the methane oversaturation observed in the oligotrophic waters of the North Pacific Subtropical Gyre. Degradation rates of d-MPn were, however, stimulated by the addition of low concentrations of nitrate and iron, suggesting regulation of the d-MPn degradation pathway by these nutrients. Degradation of d-MPn associated with sediment trap-collected particles was significantly faster than in the water column, even after normalizing to particulate organic carbon, particulate phosphorus, or heterotrophic bacterial numbers, suggesting that MPn degradation might be localized on sinking particles. We hypothesize that MPn is transformed to methane directly from sinking particles, without transitioning through the dissolved phase.
\end{abstract}

KEY WORDS: Methane - Methylphosphonate • Phosphonates - Phosphorus - Station ALOHA . Oligotrophic

Resale or republication not permitted without written consent of the publisher

\section{INTRODUCTION}

Methane $\left(\mathrm{CH}_{4}\right)$ is a biogenic gas that plays a direct role in Earth's climate, acting in the atmosphere as a greenhouse gas 25 times more potent (per mole) than carbon dioxide. $\mathrm{CH}_{4}$ is often 10 to $75 \%$ supersatu-

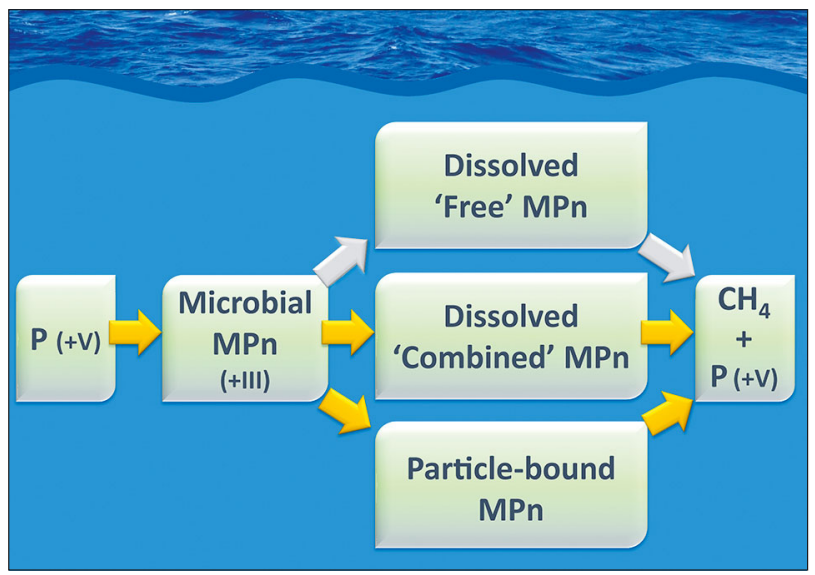

Proposed methylphosphonate (MPn) production-decomposition pathways in the ocean. Yellow arrows denote the hypothesized preferred pathways. In the dissolved phase, MPn may be free or associated with dissolved organic matter (combined)

Image: Daniela A. del Valle

rated within the oxygenated surface mixed layer in most areas of the global ocean (Lamontagne et al. 1971, 1973), making the oceans a net source of this gas to the atmosphere (Owens et al. 1991, Bange et al. 1994, Bates et al. 1996, Rhee et al. 2009). In the open ocean, these supersaturated concentrations are thought to be the product of in situ production in this oxygenated layer (Scranton \& Brewer 1977, Tilbrook \& Karl 1995). The presence of $\mathrm{CH}_{4}$ in surface waters has intrigued researchers for over $40 \mathrm{yr}$ because its production by traditional methanogenesis is not favored under aerobic conditions (Wolfe 1971, Kiene 1991, Reeburgh 2007).

The notion of methanogenic processes occurring under low oxygen concentrations directed research 
towards the study of the formation of $\mathrm{CH}_{4}$ in reducing microenvironments, e.g. interior of fecal pellets, intestinal tracts of zooplankton, or large organic particles (Scranton \& Brewer 1977, Oremland 1979, Alldredge \& Cohen 1987, Marty 1993). However, recently, it has been proposed that certain C1 compounds may be metabolized to $\mathrm{CH}_{4}$ under aerobic conditions (Damm et al. 2008, Karl et al. 2008, Damm et al. 2010, Florez-Leiva et al. 2013, Zindler et al. 2013), which has facilitated a new understanding of $\mathrm{CH}_{4}$ dynamics and opened a new line of research. A relation between dimethylsulfoniopropionate (DMSP) and $\mathrm{CH}_{4}$ concentrations was observed in a polar system (Damm et al. 2008) and it was proposed that, under conditions of nitrogen limitation (but P availability), methylotrophic methanogenesis of methanethiol (an intermediate in DMSP metabolism, Kiene et al. 2000) may be the principal pathway involved in $\mathrm{CH}_{4}$ formation (Damm et al. 2010). On the other hand, in subtropical oligotrophic systems, Karl et al. (2008) proposed that, under P-stressed conditions, the biological transformation of methylphosphonate (MPn) can act as a potential source of $\mathrm{CH}_{4}$ in the aerobic upper water column. It was shown in the Karl et al. (2008) study that MPn can be cleaved into $\mathrm{CH}_{4}$ by certain members of the microbial community present in the North Pacific Subtropical Gyre (NPSG), since marine bacterial enrichment cultures obtained by the amendment of glucose and nitrate were able to transform 1 to $10 \mu \mathrm{M}$ added MPn quantitatively to $\mathrm{CH}_{4}$. Moreover, MPn-utilization pathway genes were found in the subtropical Pacific and Atlantic Ocean, which further supported the importance of this aerobic $\mathrm{CH}_{4}$ production pathway in the oligotrophic gyres (Ilikchyan et al. 2010, Martínez et al. 2010, Luo et al. 2011). However, no studies have been performed looking at the biogeochemical relevance of any of these processes under natural conditions.

Phosphonates are organic molecules characterized by a C-P bond, which, due to their chemical stability, were assumed to experience minimal microbial degradation (Kittredge et al. 1962). Phosphonates represent a source of $\mathrm{P}$ to selected marine microbes that may not be bioavailable to the whole of the community, providing a competitive advantage to those groups. Only recently, putative genes involved in phosphonate transport and degradation were reported to be found in the genomes of Cyanobacteria, Proteobacteria, Bacteroidetes, and Firmicutes (Kononova \& Nesmeyanova 2002, Dyhrman et al. 2006, Karl et al. 2008), indicating that phosphonate degradation is a widely distributed trait among distantly related species (Huang et al. 2005, Martínez et al. 2013).
Different studies have shown that phosphonates constitute about $25 \%$ of the high molecular weight (HMW) fraction of the dissolved organic phosphorus (DOP) pool (Clark et al. 1999, Kolowith et al. 2001, Sannigrahi et al. 2006). However, phosphonates constitute a small fraction $(<6 \%)$ of the organic P present in live cells and in sinking material (Kittredge et al. 1969, Clark et al. 1998, Paytan et al. 2003), which suggests that these compounds are preferentially discriminated against during remineralization and, therefore, tend to accumulate relative to other components of the DOP pool. Using a new concentration approach based on electrodialysis followed by reverse osmosis, Young \& Ingall (2010) were able to recover jointly both the HMW and low molecular weight (LMW) components of the DOP pool, and reported a much lower contribution (5 to $10 \%$ ) of phosphonates to DOP than the percentage obtained when analyzing the HMW fraction only. This finding led the authors to suggest that LMW phosphonates might be more rapidly utilized in marine systems than HMW phosphonates. MPn is the simplest of all organo-phosphonates, but in cellular material it is found covalently linked to a polysaccharide of unknown structure (Metcalf et al. 2012); therefore, it can potentially be present in both the LMW and HMW fraction of the DOP pool. The confirmation of the presence of MPn in cellular material, as well as the report of a metabolic pathway for its biosynthesis (Metcalf et al. 2012), constitutes one more piece of evidence for its viability as an aerobic $\mathrm{CH}_{4}$ source.

The goal of this work was to estimate the role of dissolved MPn (d-MPn) in the production of $\mathrm{CH}_{4}$ in the surface waters of the NPSG. We focused our research on quantifying the transformation of free d-MPn into $\mathrm{CH}_{4}$ using a radiotracer technique, and explored the controls on d-MPn metabolism in the water column. We also studied the potential for $\mathrm{CH}_{4}$ production from sinking material and the production of $\mathrm{CH}_{4}$ from d-MPn by bacteria associated with sinking particles.

\section{MATERIALS AND METHODS}

\section{Study site and sampling}

Field samples were collected onboard the R/V 'Kilo Moana' during several cruises to Station ALOHA, the Hawaii Ocean Time-series (HOT) study site, which is located at $22^{\circ} 45^{\prime} \mathrm{N}, 158^{\circ} 00^{\prime} \mathrm{W}$ (Karl \& Lukas 1996). Samples were collected on the following cruises: HOT cruise 239 (17-21 January 2012), HOT cruise 
240 (23-27 March 2012), HOE-DYLAN IX (Hawaii Ocean Experiment - DYnamics of Light And Nutrients, 22 August-11 September 2012), and HOE-PhoR I and II (Hawaii Ocean Experiment - Phosphorus Rally, 22 May-5 June and 16-28 September 2013). Seawater sampling was carried out using 12-l PVC sample bottles attached to a CTD rosette. Sinking particles were collected using unpreserved cylindrical traps attached to PVC crosses that were deployed at specific depths, with each cross holding up to 12 traps. A detailed description of the traps and array can be found in Karl \& Knauer (1984). In summer, each trap was fitted with a $335 \mu \mathrm{m}$ Nitex mesh at the base of the baffle to prevent the intrusion of actively swimming zooplankton. The traps contained approximately 1.81 of $0.2 \mu \mathrm{m}$ filtered solution, consisting of sterile seawater amended with $33.8 \mathrm{~g} \mathrm{l}^{-1} \mathrm{NaCl}, 14.26 \mathrm{~g} \mathrm{l}^{-1}$ $\mathrm{MgCl}_{2} \cdot 6 \mathrm{H}_{2} \mathrm{O}$, and $0.93 \mathrm{~g} \mathrm{l}^{-1} \mathrm{KCl}$ (density: $1.06 \mathrm{~g} \mathrm{~cm}^{-3}$ ). The higher density, compared to adjacent seawater, is required to minimize flushing of the collected particles and prevent mixing of the trap solution with the in situ seawater (Karl \& Knauer 1984). The sediment trap array was deployed for 8 to $10 \mathrm{~d}$.

Production of $\mathrm{CH}_{4}$ from d-MPn in the water column

Seawater from $25 \mathrm{~m}$ depth and from the deep chlorophyll maximum (DCM) was transferred from the PVC sample bottles into 2- or 4.5-1 polycarbonate (PC) bottles and capped with septum closure caps (Thermo Scientific). ${ }^{14} \mathrm{C}-\mathrm{MPn}$ was custom synthesized by ViTrax with a specific activity of $2.18 \mathrm{GBq}$ $\mathrm{mmol}^{-1}$ and a radiochemical purity of $>99 \% .{ }^{14} \mathrm{C}$ MPn was added in a series with $0.2,0.5$, and $1 \mathrm{nM}$ final concentrations (equivalent to $0.437,1.09$, and $2.18 \mathrm{kBq}^{-1}$, respectively), each in triplicate. Samples were incubated for $24 \mathrm{~h}$ in a deckboard incubator under blue Plexiglas at $20 \%$ attenuation solar radiation (25 m depth samples) or in the dark (DCM samples). Post-incubation, samples were fixed by injecting saturated $\mathrm{HgCl}_{2}$ (final concentration: $0.27 \mathrm{mM}$ ) and processed within $24 \mathrm{~h}$, with the exception of samples collected on HOE-DYLAN IX which were kept at $4^{\circ} \mathrm{C}$ for $6 \mathrm{~d}$ until analyses.

Because there are no methodological approaches available for the direct measurement of d-MPn concentrations in seawater, amendments of 0.2 to $1 \mathrm{nM}$ ${ }^{14} \mathrm{C}$-MPn could not be assumed to be tracer additions; therefore, we utilized an isotope dilution approach to estimate the turnover time for d-MP $\mathrm{P}_{\mathrm{n}}$ under in situ MPn concentrations in the water column (WC). The turnover time for d-MPn cleavage for each individual amendment was calculated as the inverse of the process rate constant, which in turn was obtained by dividing the fraction of ${ }^{14} \mathrm{C}$-MPn converted to ${ }^{14} \mathrm{C}$ $\mathrm{CH}_{4}$ (see 'Analytical measurements') by the incubation time. It must be noted that when we refer to turnover time of d-MPn, we are referring exclusively to the turnover time due to the conversion of d-MPn into $\mathrm{CH}_{4}$. d-MPn could be removed from the dissolved fraction by other processes, e.g. incorporation into the cell with or without transformation of the $\mathrm{C}$ moiety, or oxidation of the methyl group to $\mathrm{CO}_{2}$. However, the conversion of micromolar concentrations of d-MPn into $\mathrm{CH}_{4}$ in seawater (Karl et al. 2008) and in Trichodesmium cultures (Beversdorf et al. 2010) appears to be stoichiometric. In agreement with these previous results, we were not able to detect production of ${ }^{14} \mathrm{C}-\mathrm{CO}_{2}$ from ${ }^{14} \mathrm{C}-\mathrm{MPn}$ consumption or assimilation of the label into cellular material collected from $25 \mathrm{~m}$ depth or the DCM (data not shown). The resulting turnover times from individual samples were plotted against the corresponding concentration of added ${ }^{14} \mathrm{C}-\mathrm{MPn}$. Data were fitted using linear regression and the absolute value of the intercept of the regression line with the $y$-axis and $x$-axis were considered as an estimate of the turnover time for ambient MPn concentration and an estimate for the in situ d-MPn concentration, respectively (Wright \& Hobbie 1966). The inverse of this calculated turnover time represents the rate constant for the process under the in situ d-MPn concentration, hereafter referred to as $k_{\mathrm{WC}}$.

$$
\begin{aligned}
& \text { Effect of } \mathrm{Fe}(\mathrm{II}) \text { and nitrate }\left(\mathrm{NO}_{3}^{-}\right) \text {on } \mathrm{CH}_{4} \\
& \text { production from d-MPn }
\end{aligned}
$$

Five experiments were conducted in which seawater from $25 \mathrm{~m}$ depth was collected in $21 \mathrm{PC}$ bottles and amended with $3 \mathrm{nM}{ }^{14} \mathrm{C}-\mathrm{MPn}$ (controls), $3 \mathrm{nM}$ ${ }^{14} \mathrm{C}-\mathrm{MPn}$ and $3 \mathrm{nM} \mathrm{Fe}(\mathrm{II})$, or $3 \mathrm{nM}{ }^{14} \mathrm{C}-\mathrm{MPn}$ and $100 \mathrm{nM} \mathrm{NO}_{3}{ }^{-}$. Samples were incubated under in situ light and temperature conditions for $48 \mathrm{~h}$, and processed to quantify the amount of ${ }^{14} \mathrm{C}_{-}-\mathrm{CH}_{4}$ produced. Because the production of ${ }^{14} \mathrm{C}-\mathrm{CH}_{4}$ was assessed after the amendment of only one non-tracer concentration of ${ }^{14} \mathrm{C}$-MPn (instead of a series of concentrations, as employed for the in situ rate constant, see above), we report the results of these experiments as the rate of production of ${ }^{14} \mathrm{C}_{-} \mathrm{CH}_{4}$ from the added ${ }^{14} \mathrm{C}-\mathrm{MPn}$ in $\mathrm{pM} \mathrm{d}^{-1}$. This approach is utilized in all experiments in which only one concentration of ${ }^{14} \mathrm{C}-\mathrm{MPn}$ was added. Samples for nutrient analysis were taken at the beginning and end of the incubation in all treatments. 


\section{Production of $\mathrm{CH}_{4}$ from d-MPn by Trichodesmium colonies}

Trichodesmium colonies were collected from the upper $10 \mathrm{~m}$ of the water column using a $20 \mu \mathrm{m}$ net. The most abundant colony morphology during the sampling period was fusiform; therefore, this type of morphology was chosen for the experiments. Trichodesmium colonies were individually picked with a sterile plastic inoculation loop, washed in $0.2 \mu \mathrm{m}$ filtered $10 \mathrm{~m}$ seawater, and then transferred into $70 \mathrm{ml}$ serum vials containing $0.2 \mu \mathrm{m}$ filtered $10 \mathrm{~m}$ seawater amended with $10 \mathrm{nM}{ }^{14} \mathrm{C}-\mathrm{MPn}$ (-Fe treatment) or $10 \mathrm{nM}{ }^{14} \mathrm{C}-\mathrm{MPn}$ and $3 \mathrm{nM} \mathrm{Fe}(\mathrm{II})$ (+Fe treatment). Serum vials were sealed using a Teflon-coated, butyl rubber stopper and crimp sealed with an aluminum collar. Controls consisted of $0.2 \mu \mathrm{m}$ filtered seawater under the same treatments but without any Trichodesmium colonies. Production of ${ }^{14} \mathrm{C}^{-} \mathrm{CH}_{4}$ in controls was below detection limit $\left(<0.5 \mathrm{pM}{ }^{14} \mathrm{C}^{-} \mathrm{CH}_{4} \mathrm{~d}^{-1}\right)$. Incubations were conducted in a deckboard incubator at in situ temperature and under $20 \%$ surface irradiance. After a $24 \mathrm{~h}$ incubation period samples were killed by injecting $70 \mu \mathrm{l}$ of a saturated $\mathrm{HgCl}_{2}$ solution (final concentration: $0.27 \mathrm{mM}$ ) and analyzed within $24 \mathrm{~h}$.

\section{Production of $\mathrm{CH}_{4}$ from MPn in sinking particles}

Following recovery of the array, the sediment trap collected particles were well mixed and distributed into a series of $240 \mathrm{ml}$ serum bottles. ${ }^{14} \mathrm{C}$-MPn was added at different concentrations following the same procedures used for the WC samples, and incubated for $24 \mathrm{~h}$ in the dark. Replicate sediment traps, deployed at the same depth as those used for MPn experiments, were analyzed for $\mathrm{CH}_{4}$ and $\mathrm{O}_{2}$, and for particulate organic carbon (POC) and phosphorus (PP) (see 'Analytical measurements' for details).

An experiment was carried out to test for the production of $\mathrm{CH}_{4}$ from sinking material, without any external MPn amendment. Sediment trap-collected particulate material from 130, 140, and $150 \mathrm{~m}$ depth, along with the trap solution, was combined in a $10 \mathrm{l}$ PC carboy. The mixture was then gently sparged with $\mathrm{CH}_{4}$-free air to reduce the concentration of $\mathrm{CH}_{4}$ initially present in the samples and, therefore, facilitate the observation of changes in $\mathrm{CH}_{4}$ concentration during the subsequent incubation period. The sample was distributed randomly into several $240 \mathrm{ml}$ serum bottles which were then assigned to different treatments. Samples were either (1) killed immediately with $\mathrm{HgCl}_{2}$ (negative control), (2) unamended (positive control), or (3) amended with $1.1 \mu \mathrm{M}$ glucose and $1 \mu \mathrm{M} \mathrm{NaNO}$ (+CN treatment), or (4) amended as the $+\mathrm{CN}$ treatment plus $0.5 \mu \mathrm{M}$ $\mathrm{K}_{2} \mathrm{HPO}_{4}$ (+CNP treatment). Samples were incubated in the dark at $23^{\circ} \mathrm{C}$. Parallel samples were incubated for inorganic phosphorus (Pi) and $\mathrm{O}_{2}$ concentrations, as well as counts of heterotrophic bacteria. Two replicates per treatment were sacrificed after $72 \mathrm{~h}$ for $\mathrm{CH}_{4}$ concentration measurement. At this time, no significant changes in $\mathrm{CH}_{4}$ concentrations were observed; therefore, the remaining vials (3 replicates per treatment) were spiked with $11 \mu \mathrm{M}$ glucose, $10 \mu \mathrm{M} \mathrm{NaNO}$, or $5 \mu \mathrm{M} \mathrm{K}_{2} \mathrm{HPO}_{4}$, according to the treatments previously assigned, and incubated for another $72 \mathrm{~h}$.

\section{Analytical measurements}

\section{Quantification of produced ${ }^{14} \mathrm{C}-\mathrm{CH}_{4}$ from ${ }^{14} \mathrm{C}-\mathrm{MPn}$}

This procedure was based on the catalytic oxidation of ${ }^{14} \mathrm{C}-\mathrm{CH}_{4}$ to ${ }^{14} \mathrm{C}-\mathrm{CO}_{2}$, followed by trapping of the produced ${ }^{14} \mathrm{C}-\mathrm{CO}_{2}$. Before processing the sample, a 1 to $3 \mathrm{ml}$ aliquot was pipetted into scintillation cocktail (Ecolume, Perkin-Elmer) and counted to corroborate the amount of ${ }^{14} \mathrm{C}-\mathrm{MPn}$ added to the sample. Subsequently, a known volume of sample was pipetted out and discarded to facilitate sparging. The ${ }^{14} \mathrm{C}-\mathrm{CH}_{4}$ produced during the incubation was stripped from the sample by bubbling air through a bubbling stone placed on the bottom of the PC bottle or through an 18 gauge needle when serum bottles were utilized. The stripped gas was passed through a column containing Drierite and Ascarite to remove $\mathrm{H}_{2} \mathrm{O}$ vapor and $\mathrm{CO}_{2}$, respectively, before passing through a second column packed with $\mathrm{CuO}$ on alumina (Sigma-Aldrich) and maintained at $900^{\circ} \mathrm{C}$ in a tube furnace, in order to oxidize ${ }^{14} \mathrm{C}-\mathrm{CH}_{4}$ to ${ }^{14} \mathrm{C}-\mathrm{CO}_{2}$. The exiting gas stream was passed through a scintillation vial containing $2 \mathrm{ml}$ of Carbo-Sorb E (Perkin-Elmer) to trap any ${ }^{14} \mathrm{C}-\mathrm{CO}_{2}$ produced. To ensure that all ${ }^{14} \mathrm{C}$ $\mathrm{CO}_{2}$ produced was trapped in this vial, a second, inline vial containing Carbo-Sorb E was connected to the system. The activity in this second vial was not significantly different from a reagent blank (typically $0.12 \mathrm{~Bq}$ per vial), indicating that the use of only 1 vial with Carbo-Sorb E was sufficient to trap all ${ }^{14} \mathrm{C}_{-} \mathrm{CO}_{2}$ produced $(0.25$ to $8 \mathrm{~Bq})$. After the ${ }^{14} \mathrm{C}_{-}-\mathrm{CO}_{2}$ was trapped, $2 \mathrm{ml}$ of Permafluor $\mathrm{E}^{+}$scintillation fluid (Perkin-Elmer) was added to each scintillation vial. Activity was then counted using a Packard Tri-Carb 
2770TR/SL liquid scintillation analyzer. No significant ${ }^{14} \mathrm{C}_{-} \mathrm{CH}_{4}$ production was observed in $\mathrm{HgCl}_{2}$ treated, negative controls. ${ }^{14} \mathrm{C}-\mathrm{CH}_{4}$ standards were processed at the beginning and end of each run to obtain a conversion efficiency factor for the system (85 to $95 \%$ ), which was then used to correct the results obtained.

\section{$\mathrm{CH}_{4}$, dissolved nutrients, $\mathrm{POC} / \mathrm{PP}$ and $\mathrm{O}_{2}$ determinations}

$\mathrm{CH}_{4}$ concentrations were determined using a cryotrap concentration system, followed by a gas chromatograph (Agilent 7980A) with a flame ionization detector, as previously described (Tilbrook \& Karl 1995).

Samples for dissolved nutrients were collected in $60 \mathrm{ml}$ PC bottles and frozen immediately after collection until time of analysis. Nutrients were analyzed following the analytical procedures employed by the HOT program (http://hahana.soest.hawaii.edu/hot/ methods/results.html).

Samples for POC and PP determination were collected onto $25 \mathrm{~mm}$ diameter, combusted, and acidwashed glass fiber filters (GF/F, Whatman). Samples were analyzed following procedures utilized by the HOT program (http://hahana.soest.hawaii.edu/hot/ methods/pcpn.html).

$\mathrm{O}_{2}$ concentrations in experiments were determined by membrane inlet mass spectrometry as described in Wilson et al. (2014). Water column $\mathrm{O}_{2}$ profiles were obtained using an $\mathrm{O}_{2}$ sensor (ISUS, version 3, Satlantic), calibrated against $\mathrm{O}_{2}$ concentrations determined from Winkler titrations of discrete samples.

\section{Heterotrophic bacterial cell counts}

Several replicated $1.8 \mathrm{ml}$ samples were fixed with $0.24 \%$ paraformaldehyde (final concentration), flashfrozen using liquid $\mathrm{N}_{2}$, and stored at $-80^{\circ} \mathrm{C}$. For analysis, samples were thawed and sonicated in a water bath at $0^{\circ} \mathrm{C}$ in order to dislodge bacteria attached to sedimenting particles, following the procedures detailed in Duhamel \& Jacquet et al. (2006). Samples were stained with SYBR Green I DNA dye (Marie et al. 1997) and counted using an Attune Acoustic
Focusing Cytometer coupled to the Attune Cytometric Software (Life Technologies).

\section{RESULTS}

\section{Production of $\mathrm{CH}_{4}$ from d-MPn in seawater}

In situ rate constants were estimated from turnover times which, in turn, were obtained from extrapolation of the linear fit between the concentration of d-MPn added to each amended sample and the corresponding calculated turnover time. A selection of the resulting plots and linear fits are shown in Fig. 1. Results are summarized in Table 1. Rate constants for the conversion of d-MPn to $\mathrm{CH}_{4}$ in the water column $\left(k_{\mathrm{WC}}\right)$ were low, ranging from 5.7 to $21.6 \times 10^{-5} \mathrm{~d}^{-1}$ at $25 \mathrm{~m}$ depth to 3.4 to $8.6 \times$ $10^{-5} \mathrm{~d}^{-1}$ at the DCM. Estimated d-MPn concentrations ranged from 0.38 to $0.65 \mathrm{nM}$ at $25 \mathrm{~m}$ depth to 0.83 to $1.83 \mathrm{nM}$ in the DCM. During the time these rates were collected, temperature, density, and oxygen concentration were within the range generally encountered at Station ALOHA (Fig. 2). In contrast, inorganic phosphorus (Pi) concentrations were high, especially during May 2013, with concentrations ranging from 0.16 to $0.18 \mu \mathrm{M}$ in the surface mixed layer, which is $\sim 2$ times higher than the historical average for that month. $\mathrm{CH}_{4}$ oversaturation of $40 \%$ and $16 \%$ was observed in surface waters in September 2012 and 2013, respectively, and $\mathrm{CH}_{4}$ oversaturation was also observed at Station ALOHA before $(27 \%, 18$ May 2013$)$ and after $(18 \%, 26$ June 2013) the HOE-PhoR I cruise (22 May-5 June 2013).

Table 1. Estimated rate constants for the production of $\mathrm{CH}_{4}$ from d-MPn ( $k_{\mathrm{WC}}$ ) and estimated in situ d-MPn concentration in the water column of Station ALOHA. Also shown are inorganic phosphorus (Pi) concentrations. SE: standard error

\begin{tabular}{|c|c|c|c|c|c|c|}
\hline \multirow[t]{2}{*}{ Date } & \multirow{2}{*}{$\begin{array}{c}\text { Depth } \\
\text { (m) }\end{array}$} & \multirow{2}{*}{$\begin{array}{c}\mathrm{Pi} \\
(\mu \mathrm{M})\end{array}$} & \multicolumn{2}{|c|}{ Estimated $k_{\mathrm{WC}}\left(\mathrm{d}^{-1}\right)$} & \multicolumn{2}{|c|}{ Estimated d-MPn (nM } \\
\hline & & & Mean & SE & Mean & $\mathrm{SE}$ \\
\hline 9-Sep-12 & 25 & 0.13 & $5.7 \times 10^{-5}$ & $1.2 \times 10^{-5}$ & 0.65 & 0.20 \\
\hline 23-May-13 & 25 & 0.17 & $21.6 \times 10^{-5}$ & $2.8 \times 10^{-5}$ & 0.49 & 0.08 \\
\hline 26-May-13 & 25 & 0.18 & $18.4 \times 10^{-5}$ & $3.0 \times 10^{-5}$ & 0.44 & 0.09 \\
\hline 29-Мау-13 & 25 & 0.18 & $14.9 \times 10^{-5}$ & $1.9 \times 10^{-5}$ & 0.56 & 0.09 \\
\hline 26-Sep-13 & 25 & 0.09 & $16.3 \times 10^{-5}$ & $2.6 \times 10^{-5}$ & 0.38 & 0.07 \\
\hline 9-Sep-12 & $142^{\mathrm{a}}$ & $0.16^{\mathrm{b}}$ & $3.4 \times 10^{-5}$ & $0.6 \times 10^{-5}$ & 1.83 & 0.98 \\
\hline 23-May-13 & $140^{\mathrm{a}}$ & $0.08^{\mathrm{b}}$ & $8.6 \times 10^{-5}$ & $0.9 \times 10^{-5}$ & 0.83 & 0.14 \\
\hline 26-May-13 & $145^{\mathrm{a}}$ & $0.09^{b}$ & $7.0 \times 10^{-5}$ & $1.1 \times 10^{-5}$ & 1.23 & 0.42 \\
\hline 29-May-13 & $125^{\mathrm{a}}$ & 0.10 & $8.6 \times 10^{-5}$ & $1.0 \times 10^{-5}$ & 1.05 & 0.22 \\
\hline
\end{tabular}



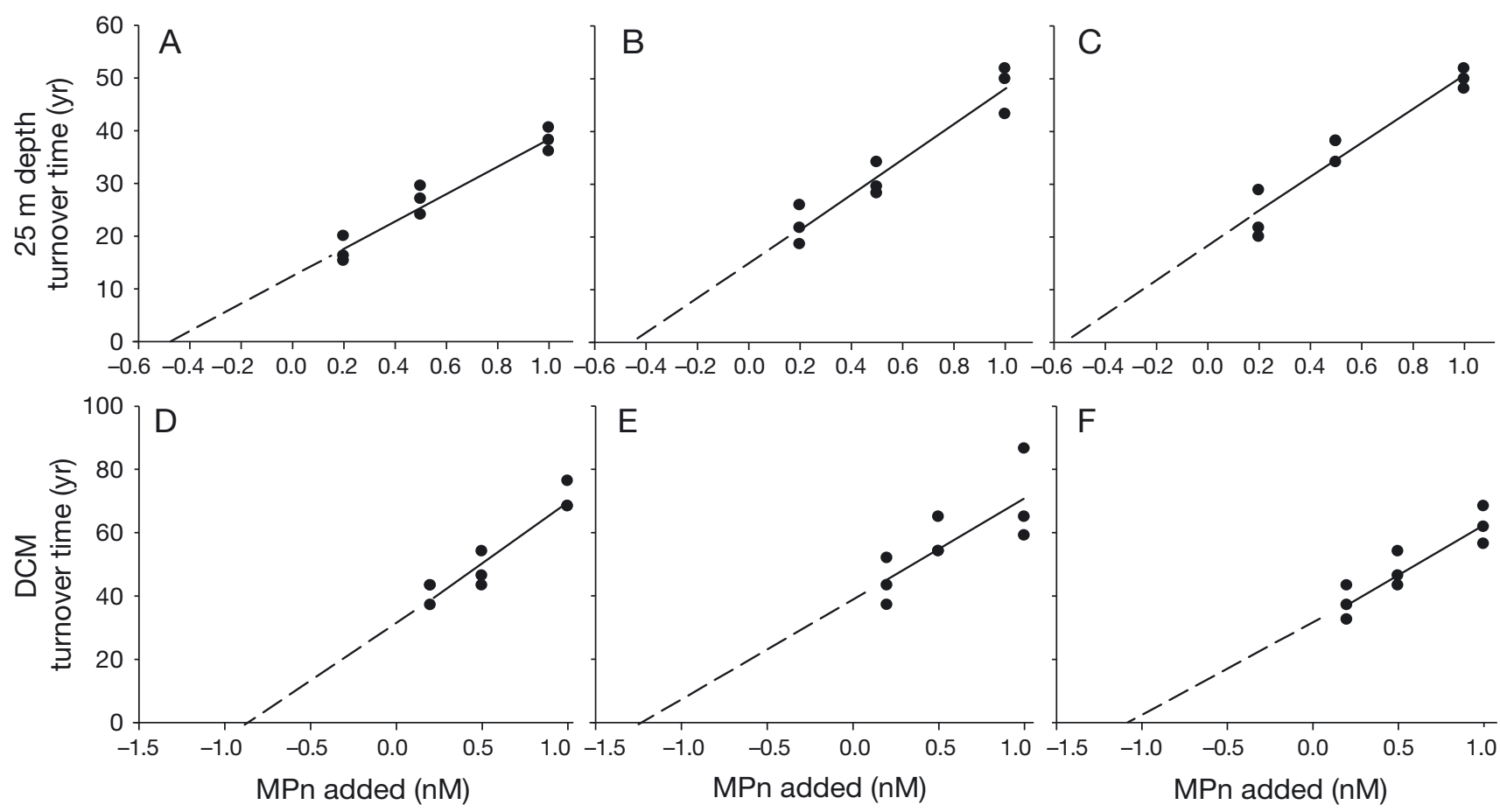

Fig. 1. Turnover time for $\mathrm{CH}_{4}$ production from d-MPn as a function of added d-MPn concentration for sewater from $25 \mathrm{~m}$ depth (A, 23 May 2013; B, 26 May 2013; C, 29 May 2013) and from the deep chlorophyll maximum (DCM) (D, 23 May 2013 ; E, 26 May 2013; F, 29 May 2013). The solid line denotes the best linear fit of the data points and the dashed line is the extrapolation of the linear fit used to estimate the rate constants for the production of $\mathrm{CH}_{4}$ from d-MPn $\left(k_{\mathrm{WC}}\right)$ and in situ d-MPn concentrations presented in Table 1 (see 'Materials and methods')

\section{Effect of nitrate and $\mathrm{Fe}(\mathrm{II})$ on $\mathrm{CH}_{4}$ production from d-MPn}

Addition of either $100 \mathrm{nM} \mathrm{NO}_{3}^{-}$or $3 \mathrm{nM} \mathrm{Fe(II)}$ resulted in a significant increase in $\mathrm{CH}_{4}$ production from d-MPn compared to the control (Fig. 3, Oneway ANOVA, $\mathrm{p}<0.05)$. Addition of $\mathrm{NO}_{3}{ }^{-}$stimulated $\mathrm{CH}_{4}$ production by a factor of 1.7 to 2.8 (mean: 2.2), while addition of $\mathrm{Fe}(\mathrm{II})$ promoted an increase of 3.8 to 23.0 (mean: 8.4) times over the control. Addition of $\mathrm{Fe}(\mathrm{II})$ did not significantly affect the concentrations of $\mathrm{Pi}$ throughout the incubation; however, $\mathrm{NO}_{3}^{-}$addition caused a decrease of 9 to $11 \%$ in the concentration of Pi compared to initial conditions. This decrease in $\mathrm{Pi}$ is consistent with net $\mathrm{P}$ uptake by microorganisms in the $\mathrm{NO}_{3}{ }^{-}$amended samples.

\section{Production of $\mathrm{CH}_{4}$ from MPn by Trichodesmium colonies}

\footnotetext{
${ }^{14} \mathrm{C}-\mathrm{CH}_{4}$ production rates by Trichodesmium colonies after an addition of $10 \mathrm{nM}{ }^{14} \mathrm{C}-\mathrm{MPn}$ ranged from 0.50 to 0.65 pmol colony $^{-1} \mathrm{~d}^{-1}$ (Table 2). Addition of Fe(II) significantly ( $t$-test, $\mathrm{p}<0.05$ ) increased these rates by a factor of 1.3 to 1.6 .
}

\section{Potential for production of $\mathrm{CH}_{4}$ from sinking material}

No significant changes in $\mathrm{CH}_{4}$ concentrations were observed in either the negative or the positive control throughout the incubation (Table 3). Significant production of $\mathrm{CH}_{4}$ from sinking material was observed when the collected sedimenting sample was amended with a $\mathrm{C}$ and $\mathrm{N}$ source (+CN treatment). However, when the sample was amended with $\mathrm{C}, \mathrm{N}$, and $\mathrm{P}$ (+CNP treatment), no significant increase in $\mathrm{CH}_{4}$ concentration above the live control was observed. By the end of the incubation period, $\mathrm{O}_{2}$ concentrations in the $+\mathrm{CN}$ and +CNP treatments were 75 and $73 \%$ of the saturation concentration, significantly lower than the $\mathrm{O}_{2}$ concentration in the live control (93\% saturation).

\section{Production of $\mathrm{CH}_{4}$ from d-MPn in sinking material}

Rate constants for the production of $\mathrm{CH}_{4}$ from dMPn in sinking particles $\left(k_{\mathrm{SP}}\right)$ were 238 to 286 times higher than for seawater $\left(k_{\mathrm{WC}}\right)$ (Table 4$)$. When $k_{\mathrm{SP}}$ was normalized to the corresponding amount of POC or $\mathrm{PP}$, the normalized $k_{\mathrm{SP}}$ was still higher than the normalized $k_{\mathrm{WC}}$ by a factor of 1.9 to 9.0 for POC or 1.7 

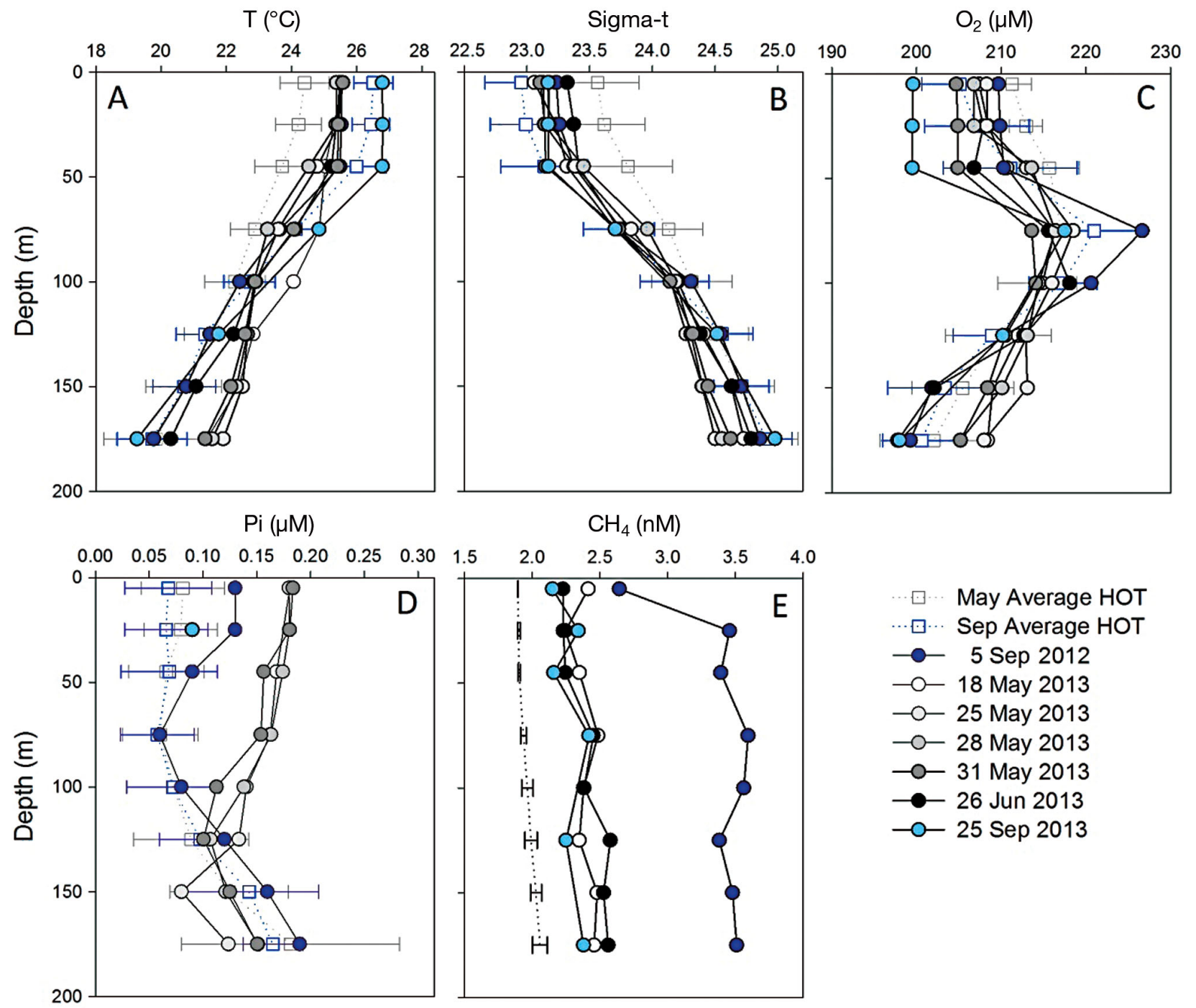

Fig. 2. Depth profiles of (A) temperature, (B) potential density, (C) oxygen concentration, (D) inorganic phosphorus (Pi), and (E) $\mathrm{CH}_{4}$ concentrations at Station ALOHA during the time of sampling. Also shown, monthly averages for May and September measured by the Hawaii Ocean Time-series (HOT) program (1998-2012, http://hahana.soest.hawaii.edu/hot/hot-dogs/ interface.html). The dotted line in panel E represents the average theoretical concentrations of $\mathrm{CH}_{4}$ in equilibrium with the atmosphere for the 4 dates shown. Error bars denote standard deviation

Table 2. Production of ${ }^{14} \mathrm{C}-\mathrm{CH}_{4}$ after a $48 \mathrm{~h}$ incubation of Trichodesmium colonies in seawater from $10 \mathrm{~m}$ depth amended with $10 \mathrm{nM}{ }^{14} \mathrm{C}-\mathrm{MPn}$ either with $(+\mathrm{Fe})$ or without (-Fe) $3 \mathrm{nM} \mathrm{Fe(II)} \mathrm{addition.} \mathrm{SD:} \mathrm{standard} \mathrm{deviation} \mathrm{from}$ triplicate measurements

\begin{tabular}{|lcccc|}
\hline \multirow{2}{*}{ Date } & Treatment & \multicolumn{3}{c|}{$\begin{array}{c}\mathrm{CH}_{4} \text { produced from d-MPn } \\
\text { (pmol colony }\end{array}$} \\
& & Mean & $\mathrm{d}^{-1}$ ) \\
& & $\mathrm{SD}$ & $\mathrm{p} t$-test \\
\hline 25-May-13 & $-\mathrm{Fe}$ & 0.65 & 0.22 & - \\
28-May-13 & $-\mathrm{Fe}$ & 0.50 & 0.12 & 0.041 \\
& $+\mathrm{Fe}$ & 0.78 & 0.11 & \\
2-Jun-13 & $-\mathrm{Fe}$ & 0.62 & 0.09 & 0.033 \\
& $+\mathrm{Fe}$ & 0.82 & 0.06 & \\
\hline
\end{tabular}

to 10.5 for PP-normalized $k$. Normalization with respect to the number of heterotrophic bacteria numbers also yielded a higher $k_{\mathrm{SP}}$ than $k_{\mathrm{WC}}$ (41 to 60 -fold). Concentration of $\mathrm{O}_{2}$ in the trap solution at the time of the recovery was $82 \%$ (September 2012), $76 \%$ (June 2013), and $82 \%$ (September 2013) of the equilibrium concentration (i.e. deployment concentration).

\section{DISCUSSION}

Production of $\mathrm{CH}_{4}$ from the aerobic metabolism of MPn has been proposed as one of the potential mechanisms to explain the oversaturation of $\mathrm{CH}_{4}$ 

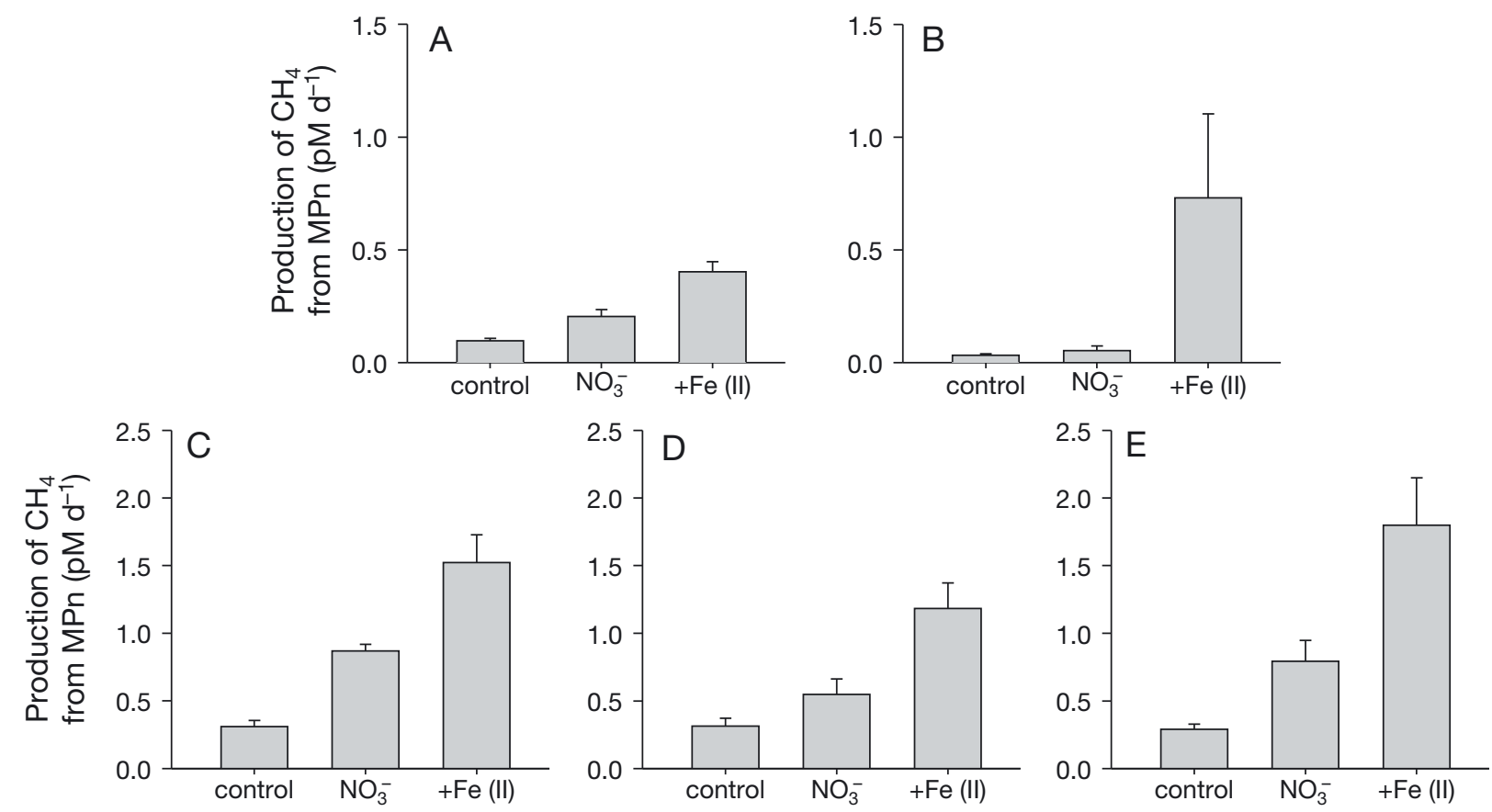

Fig. 3. Rates of ${ }^{14} \mathrm{C}-\mathrm{CH}_{4}$ production after addition of $3 \mathrm{nM}{ }^{14} \mathrm{C}-\mathrm{MPn}$ in unamended (control), $+\mathrm{NO}_{3}{ }^{-}(100 \mathrm{nM})$, and $+\mathrm{Fe}(\mathrm{II})$ (3 nM) treatments from experiments performed on (A) 20 January 2012, (B) 26 March 2012, (C) 24 May 2013, (D) 28 May 2013, and (E) 3 June 2013. Error bars represent standard deviation $(n=3)$. Differences among all treatments are significant for all experiments $(A N O V A, p<0.05)$

Table 3. Production of $\mathrm{CH}_{4}$ from sinking particles after amendment of sediment trap solution with $\mathrm{C}$ and $\mathrm{N}(+\mathrm{CN})$ or $\mathrm{C}, \mathrm{N}$ and $\mathrm{P}(+\mathrm{CNP})$. Unamended samples were kept alive during the incubation or killed with $\mathrm{HgCl}_{2}$ at the beginning of the incubation to act as positive and negative controls, respectively. $T_{0}$ stands for the time point taken before the amendment and $T_{f}$ stands for the time point after $6 \mathrm{~d}$ incubation (see 'Materials and methods' for details). Data are mean $\pm \mathrm{SD}_{;}-$: no data

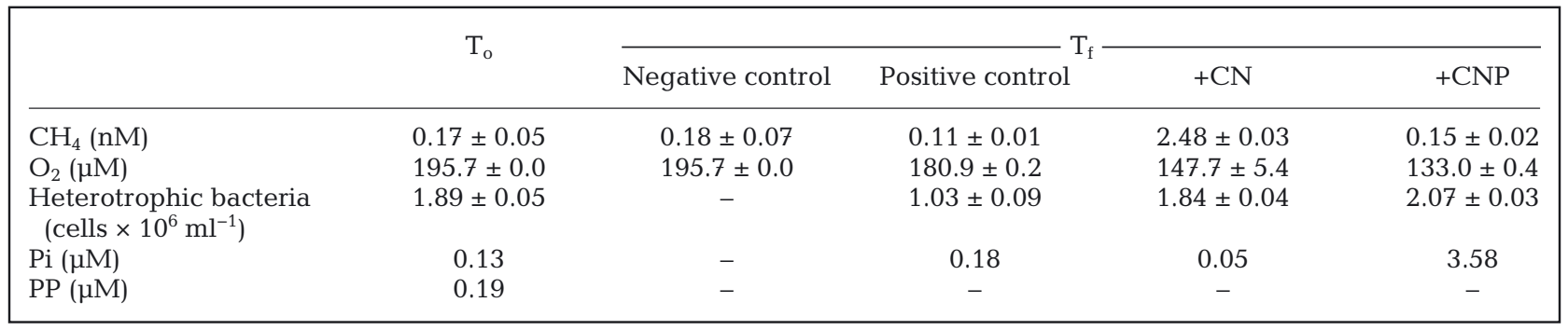

Table 4. Comparison of rate constants for the conversion of d-MPn into $\mathrm{CH}_{4}$ between water column ( $\left.k_{\mathrm{WC}}\right)$ and sinking particles $\left(k_{\mathrm{SP}}\right)$ collected at the corresponding water column (WC) depth. The estimated rate constants were normalized by the corresponding particulate organic carbon (POC-Norm. $k$ ), particulate phosphorus (PP-Norm. $k$ ), or number of heterotrophic bacteria (HB-Norm. $k$ ), to allow for a more direct comparison. na: not available. ${ }^{*}$ Statistically significant difference between WC and $\mathrm{SP}, t$-test, $\mathrm{p}<0.05$

\begin{tabular}{|c|c|c|c|c|c|c|c|c|c|c|c|}
\hline \multirow[t]{2}{*}{ Date } & \multirow[t]{2}{*}{$\begin{array}{l}\text { Depth } \\
(\mathrm{m})\end{array}$} & \multicolumn{2}{|c|}{$\begin{array}{c}\mathrm{O}_{2} \\
(\mu \mathrm{M})\end{array}$} & \multicolumn{2}{|c|}{$\begin{array}{c}k \\
\left(d^{-1}\right)\end{array}$} & \multicolumn{2}{|c|}{$\begin{array}{l}\text { POC-Norm. } k \\
\left(\mathrm{l} \mathrm{mmol}^{-1} \mathrm{yr}^{-1}\right)\end{array}$} & \multicolumn{2}{|c|}{$\begin{array}{c}\text { PP-Norm. } k \\
\left(1 \mathrm{~mol}^{-1} \mathrm{yr}^{-1}\right)\end{array}$} & \multicolumn{2}{|c|}{$\begin{array}{l}\text { HB-Norm. } k \\
\left(\mu \mathrm{c} \text { cell }^{-1} d^{-1}\right)\end{array}$} \\
\hline & & WC & $\mathrm{SP}^{\mathrm{a}}$ & $\mathrm{WC}$ & SP & WC & $\mathrm{SP}$ & WC & $\mathrm{SP}$ & WC & $\mathrm{SP}$ \\
\hline Sep 2012 & 150 & 211 & 163 & $3.6 \times 10^{-5}$ & $0.010^{*}$ & 13.9 & $38.2^{*}$ & 2.6 & $4.4^{*}$ & na & na \\
\hline Jun 2013 & 140 & 208 & 151 & $6.3 \times 10^{-5}$ & $0.015^{*}$ & $24.4^{\mathrm{b}}$ & 45.9 & $4.6^{\mathrm{b}}$ & na & $1.4 \times 10^{-7}$ & $57.2 \times 10^{-7^{*}}$ \\
\hline Sep 2013 & 130 & 206 & 159 & $4.2 \times 10^{-5}$ & $0.012^{*}$ & $13.6^{b}$ & $122.3^{*}$ & $2.1^{\mathrm{b}}$ & $22.1^{*}$ & $1.0 \times 10^{-7}$ & $60.2 \times 10^{-7^{*}}$ \\
\hline
\end{tabular}

${ }^{\mathrm{a}} \mathrm{O}_{2}$ concentration in the sediment trap solution at the time of recovery

${ }^{\mathrm{b}} \mathrm{Jun}$ and Sep $2013 k_{\mathrm{WC}}$ were normalized using a $10 \mathrm{yr}$ average (2002-2011) POC and PP for the corresponding month at Station ALOHA. Jun 2013, 150 m, POC: $0.94 \mu \mathrm{M}$, PP: 5.0 nM; Sep 2013, 125 m, POC: $1.1 \mu$, PP: 7.3 nM 
generally encountered in the surface waters of the ocean (Karl et al. 2008). Based on mass balance calculations (Table A1 in the Appendix), we estimate that $\mathrm{CH}_{4}$ production rates in the mixed layer should have ranged from 8 to $47 \mathrm{pM} \mathrm{d}^{-1}$ in order to maintain surface $\mathrm{CH}_{4}$ oversaturation at Station ALOHA during the time of the study. Assuming uniform $\mathrm{CH}_{4}$ production rates from MPn within the mixed layer, the present work indicates that d-MPn degradation would only contribute $<0.8 \%$ to the estimated total $\mathrm{CH}_{4}$ production rate in this system. Our use of ${ }^{14} \mathrm{C}-\mathrm{MPn}$ as a proxy for total MPn consumption in the water column or in sinking material assumes that, for the in situ MPn to be cleaved, it has to be available as free d-MPn in seawater. Within the cell, MPn does not appear to be present as free MPn but rather covalently linked by an ester bond to polysaccharides (Metcalf et al. 2012). Therefore, when MPn-containing cells die or are grazed, MPn may be released from the polysaccharide matrix and cleaved to $\mathrm{CH}_{4}$ without transitioning through the dissolved phase. If this is the case, our rates of d-MPn cleavage may underestimate $\mathrm{MPn}$-supported $\mathrm{CH}_{4}$ production.

Evidence for the production of $\mathrm{CH}_{4}$ directly from sinking particles (SP) has been reported previously (Owens et al. 1991, Bianchi et al. 1992, Karl \& Tilbrook 1994, Holmes et al. 2000, Sasakawa et al. 2008) but it was always attributed to $\mathrm{CH}_{4}$ production within anaerobic microhabitats. Karl \& Tilbrook (1994) proposed that $\mathrm{CH}_{4}$ is enclosed within the interstitial fluid of SP, and it is released by diffusion into the water column as the particles sink. However, production of $\mathrm{CH}_{4}$ from cell-associated MPn is a feasible mechanism that can provide an alternate explanation to these observations (Karl et al. 2008). In support of the MPn production hypothesis, we observed that $\mathrm{CH}_{4}$ production can be induced when bacteria associated with SP are forced into P-stress or P-limitation $(+\mathrm{CN}$ treatment, Table 3$)$. The fact that there was no observable production of $\mathrm{CH}_{4}$ when Pi limitation was relieved provides support to the hypothesis that the produced $\mathrm{CH}_{4}$ comes from $\mathrm{MPn}$, since $\mathrm{P}$ availability may inhibit MPn transformation into $\mathrm{CH}_{4}$ (more below). Even though the presence of anaerobic conditions in microhabitats within the SP cannot be completely ruled out, $\mathrm{O}_{2}$ was relatively abundant ( $>75 \%$ saturation) by the end of the experiment. Moreover, $\mathrm{O}_{2}$ concentrations were higher in the $+\mathrm{CN}$ compared to the +CNP treatment (Table 3); therefore, if production of $\mathrm{CH}_{4}$ was linked exclusively to $\mathrm{O}_{2}$ deprivation, we should have seen $\mathrm{CH}_{4}$ production in the $+\mathrm{CNP}$ treatment. If we assume that all $\mathrm{CH}_{4}$ produced during the incubation of SP comes from
MPn, and that all MPn present was transformed into $\mathrm{CH}_{4}$ by the end of our experiment, it can be estimated that $1 \%$ of the PP in the SP collected at 130 to $150 \mathrm{~m}$ was present as MPn. Under these assumptions, this would be a minimum estimate because some production of $\mathrm{CH}_{4}$ had already happened during the time the traps were deployed (data not shown). If $1 \%$ of the PP in the surface waters is present as MPn and has, therefore, the potential to be converted to $\mathrm{CH}_{4}$ under the right environmental conditions, then a minimal turnover of the PP pool of 2 to $9 \mathrm{~d}$ would be required in order to maintain the observed $\mathrm{CH}_{4}$ concentrations by MPn cleavage only (assuming no preferential remineralization within the PP pool). This estimate is in agreement with turnover times of the PP pool for Station ALOHA, which range from 2 to $10 \mathrm{~d}$ (Björkman \& Karl 2003), therefore making it feasible for particle-associated MPn to be a significant source of $\mathrm{CH}_{4}$ in this system.

Additional evidence for the role of SP in the transformation of MPn into $\mathrm{CH}_{4}$ can be observed from the higher potential for collected SP to cleave d-MPn into $\mathrm{CH}_{4}$ (Table 4), although a direct comparison of rates of $\mathrm{CH}_{4}$ production from MPn in SP and the water column is difficult because the sinking rates of SP are not known. Furthermore, SP were collected over a period of 8 to $10 \mathrm{~d}$, during which time the communities originally present in SP may have been positively or negatively affected by the incubation conditions. Microbes present in the collected SP may have been specifically selected for MPn cleavage if other sources of $\mathrm{P}$ were not abundant, although this effect is not expected to be important at the depths where the material was collected (130 to $150 \mathrm{~m})$ since $\mathrm{Pi}$ concentrations in the trap solution were similar to the in situ concentration at that depth. Despite these limitations, the results from the collected SP indicate that at least some of the bacteria mediating the cleavage of d-MPn into $\mathrm{CH}_{4}$ are particle-attached, and that these bacteria may be selected for within the environment of the SP, favoring the cleavage of d-MPn. Attempts to normalize the bulk rate constant in SP are also problematic. The nature, quality, and characteristics of the particulate material collected in a sedimenting trap is different from the material suspended in the water column, as well as the number and identity of the bacteria present. With those caveats in mind, when rate constants are normalized to $\mathrm{POC}$ or $\mathrm{PP}$, the normalized rate constants are higher in the SP than in the water column, again suggesting a specialization for MPn degrading bacteria. It must also be noted that in the SP, the rate constants for production of $\mathrm{CH}_{4}$ from MPn are obtained from 
the addition of d-MPn which, as previously discussed, might be underestimating the importance of this process.

Production of $\mathrm{CH}_{4}$ from d-MPn was extremely slow in the water column during our sampling period (Table 1). The unusually high Pi concentrations present at Station ALOHA (Fig. 2) may have downregulated d-MPn metabolism during May 2013. Pi is generally thought to be the preferred substrate for microbial growth since organic sources generally require enzyme-mediated remineralization. In the Sargasso Sea, expression of one of the genes involved in the transport of phosphonates (phnD) in Synechococcus is negatively influenced by high Pi concentration. In contrast, in Prochlorococcus, phnD expression appears to be independent of Pi availability maybe as a consequence of a reduction in regulatory functions due to its reduced genome (Ilikchyan et al. 2010). In laboratory studies conducted with Trichodesmium IMS101, Beversdorf et al. (2010) reported no inhibition of the production of $\mathrm{CH}_{4}$ from MPn by Pi. Also, in this study, Trichodesmium was able to utilize $\mathrm{Pi}_{\text {, }}$ MPn, and ethylphosphonate with the same metabolic efficiency, implying that Trichodesmium can metabolize multiple P sources simultaneously. In contrast, Trichodesmium colonies collected from Station ALOHA showed decreased cleavage of d-MPn into $\mathrm{CH}_{4}$ when high Pi concentrations were present (Karl et al. 2008). Moreover, using the same Trichodesmium isolate as Beversdorf et al. (2010), Dyhrman et al. (2006) showed that the expressions of the phosphonate transport gene $\mathrm{phn} D$ and the C-P lyase gene phnJ were controlled by Pi availability. Thus, in natural waters, the effect of Pi on d-MPn cleavage might be highly dependent on the community composition and, therefore, difficult to predict. At the time this study took place (2012-2013), Pi was at its highest level since the HOT program was established in 1988. The mechanisms controlling Pi dynamics in this system are not straightforward and remain unknown, with Pi concentrations being probably the result of a complex balance between biogeochemical and physical processes affected by climate-ocean interactions (Karl 2014). The fact that Pi concentrations were high during our sampling period might have inhibited the conversion of d-MPn into $\mathrm{CH}_{4}$, since the microbial community might have preferred to assimilate Pi. However, increased d-MPn cleavage rates were observed when surface seawater samples were amended with either $\mathrm{N}$ or Fe (Fig. 3), even though concentrations of $\mathrm{Pi}$ were either unaffected $(+\mathrm{Fe}$ treatment) or decreased only slightly $(+\mathrm{N}$ treatment, $<11 \%$ ) throughout the incubation, indicating that
d-MPn consumers might be $\mathrm{N}$ - or Fe-limited, rather than Pi-controlled.

Based on measurements of dissolved Fe concentrations at Station ALOHA ( 0.2 to $0.7 \mathrm{nM}$ ), it has been assumed that Fe is not limiting in this system, especially during the spring when the highest dissolved Fe concentrations are expected (Boyle et al. 2005). However, a substantial fraction of this pool is actually present as colloids (Wu et al. 2001) of unknown bioavailability (Benner 2011). Fe is a critical constituent of the nitrogen-fixing enzyme nitrogenase, and previous work at Station ALOHA has shown that nitrogen fixation responds to additions of Fe (Grabowski et al. 2008). Moreover, nitrogen-fixation rates at Station ALOHA appear to be higher during the period of higher dust delivery of Fe (March to June) (Grabowski et al. 2008), suggesting a link between diazotrophic activity and Fe input. Trichodesmium is capable of cleaving MPn via the C-P lyase (Dyhrman et al. 2006) and of growing efficiently by using MPn as its sole source of $\mathrm{P}$ (Beversdorf et al. 2010). Trichodesmium has a much higher (10-fold) Fe requirement compared to other phytoplanktonic species that are normally present in oligotrophic waters (Rueter et al. 1992). The addition of Fe to naturally occurring Trichodesmium colonies stimulated the cleavage of d-MPn by only a factor of 1.3 to 1.6 (Table 2), while the same addition of Fe to whole seawater increased d-MPn cleavage rate by a factor of 3.8 to 6.2 (Fig. 3), indicating that Trichodesmium is not the main responder to Fe addition during our sampling period. However, the high production of $\mathrm{CH}_{4}$ per Trichodesmium colony present in natural waters suggests that they might be responsible for important $\mathrm{CH}_{4}$ production during bloom conditions provided that d-MPn (and required micronutrients) is bioavailable at that time. If diazotrophs are the main group responsible for the cleavage of d-MPn into $\mathrm{CH}_{4}$, we would not expect the process to be limited by availability of $\mathrm{N}$ despite the low concentrations of inorganic $\mathrm{N}$ that are generally encountered in the surface waters of Station ALOHA. However, the addition of small quantities of $\mathrm{N}$ stimulated the consumption of d-MPn (and production of $\mathrm{CH}_{4}$ ) (Fig. 3), suggesting that other bacterial groups, besides diazotrophs, benefit from a supply of $\mathrm{N}$ and are capable of utilizing d-MPn as a source of Pi when N limitation is relieved.

\section{CONCLUSIONS}

This work shows that aerobic $\mathrm{CH}_{4}$ formation from d-MPn can occur in a natural system, both in the water column and in sinking particles. However, the 
importance of d-MPn in the production of $\mathrm{CH}_{4}$ in the surface water column might be variable and tightly linked to the $\mathrm{Fe}, \mathrm{N}$, and $\mathrm{P}$ cycles. Further work should focus on studying the relevance of this process in naturally P-limited environments. Although it might be methodologically challenging, the production of $\mathrm{CH}_{4}$ directly from MPn associated with sinking particles versus that from d-MPn warrants further investigation.

Acknowledgements. We thank Chief Scientists S. Curless (HOT 239), C. Nosse (HOT 240), S. Wilson (HOE-DYLAN IX), K. Björkman (HOE-PhoR I), and T. Clemente (HOEPhoR II) for facilitating our research objectives. We also thank all members of the Karl Lab involved in the preparation and deployment of the sediment trap arrays. S. Ferrón provided assistance in the measurement of $\mathrm{CH}_{4}$ concentrations and $\mathrm{S}$. Wilson provided the $\mathrm{CH}_{4}$ concentration profiles for HOT 252 and HOT 253. The contribution of 4 anonymous reviewers helped improve the manuscript. The research was supported by the Gordon and Betty Moore Foundation Marine Microbiology Investigator awards to D.M.K. and National Science Foundation Grant EF0424599 to D.M.K.

\section{LITERATURE CITED}

Alldredge AL, Cohen Y (1987) Can microscale chemical patches persist in the sea? Microelectrode study of marine snow, fecal pellets. Science 235:689-691

> Bange HW, Bartell U, Rapsomanikis S, Andreae MO (1994) Methane in the Baltic and North Seas and a reassessment of the marine emissions of methane. Global Biogeochem Cycles 8:465-480

Bates TS, Kelly KC, Johnson JE, Gammon RH (1996) A reevaluation of the open ocean source of methane to the atmosphere. J Geophys Res Atmos 101:6953-6961

Benner R (2011) Loose ligands and available iron in the ocean. Proc Natl Acad Sci USA 108:893-894

Beversdorf LJ, White AE, Björkman KM, Letelier RM, Karl DM (2010) Phosphonate metabolism of Trichodesmium IMS101 and the production of greenhouse gases. Limnol Oceanogr 55:1768-1778

> Bianchi M, Marty D, Teyssié JL, Fowler SW (1992) Strictly aerobic and anaerobic bacteria associated with sinking particulate matter and zooplankton fecal pellets. Mar Ecol Prog Ser 88:55-60

Björkman KM, Karl DM (2003) Bioavailability of dissolved organic phosphorus in the euphotic zone at Station ALOHA, North Pacific Subtropical Gyre. Limnol Oceanogr 48:1049-1057

> Boyle EA, Bergquist BA, Kayser RA, Mahowald N (2005) Iron, manganese, and lead at Hawaii Ocean Time-series station ALOHA: temporal variability and an intermediate water hydrothermal plume. Geochim Cosmochim Acta 69:933-952

> Clark LL, Ingall ED, Benner R (1998) Marine phosphorus is selectively remineralized. Nature 393:426

> Clark LL, Ingall ED, Benner R (1999) Marine organic phosphorus cycling: novel insights from nuclear magnetic resonance. Am J Sci 299:724-737
Damm E, Kiene RP, Schwarz J, Falck E, Dieckmann G (2008) Methane cycling in Arctic shelf water and its relationship with phytoplankton biomass and DMSP. Mar Chem 109: 45-59

> Damm E, Helmke E, Thoms S, Schauer U, Nöthig E, Bakker K, Kiene RP (2010) Methane production in aerobic oligotrophic surface water in the central Arctic Ocean. Biogeosciences 7:1099-1108

$>$ Duhamel S, Jacquet S (2006) Flow cytometric analysis of bacteria- and virus-like particles in lake sediments. J Microbiol Methods 64:316-332

> Dyhrman ST, Chappell PD, Haley ST, Moffett JW, Orchard ED, Waterbury JB, Webb EA (2006) Phosphonate utilization by the globally important marine diazotroph Trichodesmium. Nature 439:68-71

Florez-Leiva L, Damm E, Farías L (2013) Methane production induced by dimethylsulfide in surface water of an upwelling ecosystem. Prog Oceanogr 112-113:38-48

Grabowski MNW, Church MJ, Karl DM (2008) Nitrogen fixation rates and controls at Stn ALOHA. Aquat Microb Ecol 52:175-183

- Holmes ME, Sansone FJ, Rust TM, Popp BN (2000) Methane production, consumption, and air-sea exchange in the open ocean: an evaluation based on carbon isotopic ratios. Global Biogeochem Cycles 14:1-10

Huang J, Su Z, Xu Y (2005) The evolution of microbial phosphonate degradative pathways. J Mol Evol 61: 682-690

Ilikchyan IN, McKay RML, Kutovaya OA, Condon R, Bullerjahn GS (2010) Seasonal expression of the picocyanobacterial phosphonate transporter gene phnD in the Sargasso Sea. Front Microbiol 1:135

> Jones RD (1991) Carbon monoxide and methane distribution and consumption in the photic zone of the Sargasso Sea. Deep-Sea Res 38:625-635

Karl DM (2014) Microbially-mediated tranformations of phosphorus in the sea: new views of an old cycle. Annu Rev Mar Sci 6:279-337

Karl DM, Knauer GA (1984) Detritus-microbe interactions in the marine pelagic environment: selected results from the VERTEX experiment. Bull Mar Sci 35:550-565

Karl DM, Lukas R (1996) The Hawaii Ocean Time-series (HOT) program: background, rationale and field implementation. Deep-Sea Res II 43:129-156

Karl DM, Tilbrook BD (1994) Production and transport of methane in oceanic particulate organic matter. Nature 368:732-734

Karl DM, Beversdorf L, Björkman KM, Church MJ, Martínez A, DeLong EF (2008) Aerobic production of methane in the sea. Nat Geosci 1:473-478

Kiene R (1991) Production and consumption of methane in aquatic systems. In: Rodgers JE, Whitman WB (eds) Microbial production and consumption of greenhouse gases: methane, nitrogen oxides and halomethanes. Am Soc Microbiol, Washington, DC, p 111-146

Kiene RP, Linn LJ, Bruton JA (2000) New and important roles for DMSP in marine microbial communities. J Sea Res 43:209-224

Kittredge JS, Roberts E, Simonsen DG (1962) The occurrence of free 2-aminoethylphosphonic acid in the sea anemone, Anthopleura elegantissima. Biochemistry 1: 624-628

Kittredge JS, Horiguchi M, Williams PM (1969) Aminophosphonic acids: biosynthesis by marine phytoplankton. Comp Biochem Physiol 29:859-863 
Kolowith L, Ingall E, Benner R (2001) Composition and cycling of marine organic phosphorus. Limnol Oceanogr 46:309-320

Kononova SV, Nesmeyanova MA (2002) Phosphonates and their degradation by microorganisms. Biochemistry (Moscow) 67:184-195

Lamontagne R, Swinnerton J, Linnenbom V (1971) Nonequilibrium of carbon monoxide and methane at the airsea interface. J Geophys Res 76:5117-5121

Lamontagne R, Swinnerton J, Linnenbom V, Smith W (1973) Methane concentrations in various marine environments. J Geophys Res 78:5317-5324

Li YH, Peng TH, Broecker WS, Oestlund HG (1984) The average vertical mixing coefficient for the oceanic thermocline. Tellus B Chem Phys Meterol 36B:212-217

Luo H, Zhang H, Long RA, Benner R (2011) Depth distributions of alkaline phosphatase and phosphonate utilization genes in the North Pacific Subtropical Gyre. Aquat Microb Ecol 62:61-69

> Marie D, Partensky F, Jacquet S, Vaulot D (1997) Enumeration and cell cycle analysis of natural populations of marine picoplankton by flow cytometry using the nucleic acid stain SYBR Green I. Appl Environ Microbiol 63: 186-193

> Martínez A, Tyson G, DeLong E (2010) Widespread known and novel phosphonate utilization pathways in marine bacteria revealed by functional screening and metagenomic analyses. Environ Microbiol 12:222-238

Martínez A, Ventouras LA, Wilson ST, Karl DM, DeLong EF (2013) Metatranscriptomic and functional metagenomic analysis of methylphosphonate utilization by marine bacteria. Front Microbiol 4:340

Marty DG (1993) Methanogenic bacteria in seawater. Limnol Oceanogr 38:452-456

Metcalf WW, Griffin BM, Cicchillo RM, Gao JT and others (2012) Synthesis of methylphosphonic acid by marine microbes: a source for methane in the aerobic ocean. Science 337:1104-1107

Nightingale PD, Malin G, Law CS, Watson AJ, Liss PS, Liddicoat MI (2000) In situ evaluation of air-seagas exchange parameterizations using novel conservative and volatile tracers. Global Biogeochem Cycles 14:373-387

> Oremland RS (1979) Methanogenic activity in plankton samples and fish intestines: a mechanism for in situ methanogenesis in oceanic surface waters. Limnol Oceanogr 24:1136-1141

Owens N, Law C, Mantoura R, Burkill P, Llewellyn C (1991) Methane flux to the atmosphere from the Arabian Sea. Nature 354:293-296

Paytan A, Cade-Menun BJ, McLaughlin K, Faul KL (2003) Selective phosphorus regeneration of sinking marine particles: evidence from ${ }^{31} \mathrm{P}-\mathrm{NMR}$. Mar Chem 82:55-70
Reeburgh WS (2007) Oceanic methane biogeochemistry. Chem Rev 107:486-513

- Rhee T, Kettle A, Andreae M (2009) Methane and nitrous oxide emissions from the ocean: a reassessment using basin-wide observations in the Atlantic. J Geophys Res Atmos 114, D12304, doi:10.1029/2008JD011662

Rueter JG, Hutchins DA, Smith RW, Unsworth NL (1992) Iron nutrition of Trichodesmium. In: Carpenter EJ, Capone DG, Rueter JG (eds) Marine pelagic cyanobacteria: Trichodesmium and other diazotrophs. Kluwer Academic Publishers, Dordrecht, p 289-306

> Sannigrahi P, Ingall E, Benner R (2006) Nature and dynamics of phosphorus-containing components of marine dissolved and particulate organic matter. Geochim Cosmochim Acta 70:5868-5882

Sasakawa M, Tsunogai U, Kameyama S, Nakagawa F, Nojiri Y, Tsuda A (2008) Carbon isotopic characterization for the origin of excess methane in subsurface seawater. J Geophys Res C 113, C03012, doi:10.1029/2007JC004217

Scranton MI, Brewer PG (1977) Occurrence of methane in the near-surface waters of the western subtropical North-Atlantic. Deep-Sea Res 24:127-138

> Tilbrook BD, Karl DM (1995) Methane sources, distributions and sinks from California coastal waters to the oligotrophic North Pacific gyre. Mar Chem 49:51-64

Ward B, Kilpatrick K, Novelli P, Scranton M (1987) Methane oxidation and methane fluxes in the ocean surface layer and deep anoxic waters. Nature 327:226-229

Wiesenburg DA, Guinasso NL Jr (1979) Equilibrium solubilities of methane, carbon monoxide, and hydrogen in water and sea water. J Chem Eng Data 24:356-360

> Wilson ST, del Valle DA, Segura-Noguera M, Karl DM (2014) A role for nitrite in the production of nitrous oxide in the lower euphotic zone of the oligotrophic North Pacific Ocean. Deep-Sea Res I 85:47-55

Wolfe RS (1971) Microbial formation of methane. Adv Microb Physiol 6:107-146

> Wright RR, Hobbie JE (1966) Use of glucose and acetate by bacteria and algae in aquatic ecosystems. Ecology 47 : 447-464

Wu J, Boyle E, Sunda W, Wen LS (2001) Soluble and colloidal iron in the oligotrophic North Atlantic and North Pacific. Science 293:847-849

Young C, Ingall E (2010) Marine dissolved organic phosphorus composition: insights from samples recovered using combined electrodialysis/reverse osmosis. Aquat Geochem 16:563-574

> Zindler C, Bracher A, Marandino CA, Taylor B, Torrecilla E, Kock A, Bange HW (2013) Sulphur compounds, methane, and phytoplankton: interactions along a northsouth transit in the western Pacific Ocean. Biogeosciences 10:3297-3311 
Appendix. Methane budget in the mixed layer of Station ALOHA

In order to estimate the $\mathrm{CH}_{4}$ production rate necessary to maintain steady state concentrations, we performed a mass balance calculation from $\mathrm{CH}_{4}$ sources and sinks in the surface mixed layer (SML, Table A1). The SML was determined based on a potential density change from the ocean surface of $0.125 \mathrm{~kg} \mathrm{~m}^{-3}$. The net flux of $\mathrm{CH}_{4}$ from the ocean to the atmosphere was calculated using the solubility equation of Wiesenburg \& Guinasso (1979) and an atmospheric concentration of $1.8 \mathrm{ppm}$ (www.esrl.noaa.gov/gmd/obop/mlo). The gas transfer coefficient was calculated using the daily average of the $10 \mathrm{~m}$ normalized wind speed and the parameterization of Nightingale et al. (2000). The vertical eddy diffusive flux at the base of the SML was calculated using an eddy diffusion coefficient of $1.8 \mathrm{~cm}^{2} \mathrm{~s}^{-1}$ (Li et al. 1984). The concentration gradient across the SML was calculated from the $\mathrm{CH}_{4}$ concentration profiles obtained on 5 September 2012, 18 May 2013, 26 June 2013, and 25 September 2013. Based on the long turnover times previously encountered for microbial oxidation of $\mathrm{CH}_{4}\left(\mathrm{Ward}^{\mathrm{at}}\right.$ al. 1987, Jones 1991), this process was considered negligible (Tilbrook \& Karl 1995).

Table A1. Calculated $\mathrm{CH}_{4}$ flux from the ocean to the atmosphere, calculated eddy diffusion of $\mathrm{CH}_{4}$ across the mixed layer, and estimated gross $\mathrm{CH}_{4}$ production necessary to maintain $\mathrm{CH}_{4}$ steady state concentrations in the surface mixed layer (SML) of Station ALOHA during late spring and summer. Positive numbers denote sources of $\mathrm{CH}_{4}$ to the SML, while negative numbers denote losses of $\mathrm{CH}_{4}$ from the SML

\begin{tabular}{|c|c|c|c|c|}
\hline Date & $\begin{array}{l}\text { SML } \\
(\mathrm{m})\end{array}$ & $\begin{array}{l}\text { Flux to atmosphere } \\
\left(\mu \mathrm{mol} \mathrm{m} \mathrm{m}^{-2} \mathrm{~d}^{-1}\right)\end{array}$ & $\begin{array}{l}\text { Eddy diffusion } \\
\left(\mu \mathrm{mol} \mathrm{m} \mathrm{m}^{-2} \mathrm{~d}^{-1}\right)\end{array}$ & $\begin{array}{l}\text { Estimated gross production } \\
\qquad\left(\mu \mathrm{mol} \mathrm{m} \mathrm{m}^{-2} \mathrm{~d}^{-1}\right)\end{array}$ \\
\hline 5-Sep-12 & 31 & -1.41 & -0.05 & 1.46 \\
\hline 18-Мау-13 & 57 & -1.27 & 0.08 & 1.19 \\
\hline 26-Jun-13 & 56 & -0.83 & 0.10 & 0.73 \\
\hline 25-Sep-13 & 63 & -0.75 & 0.26 & 0.49 \\
\hline
\end{tabular}

Editorial responsibility: Douglas Capone, Los Angeles, California, USA
Submitted: January 20, 2014; Accepted: July 7, 2014

Proofs received from author(s): September 19, 2014 